\title{
LEARNING OBSTACLE MAHASISWA PADA FUNGSI PEMBANGKIT DITINJAU DARI KEMAMPUAN AWAL
}

\author{
Nurmitasari Nurmitasari ${ }^{1)}$, Robia Astuti ${ }^{2)}$ \\ Program studi Pendidikan Matematika, STKIP MPL

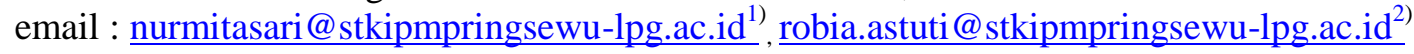

\begin{abstract}
Abstrak:
Tujuan dari penelitian ini adalah untuk mengetahui learning obstacles mahasiswa yang akan dideskripsikan berdasarkan berbagai jenis kesalahan dalam menyelesaikan soal fungsi pembangkit ditinjau dari kemampuan awal. Jenis penelitian ini adalah deskriptif dengan pendekatan kualitatif, dengan pengambilan subjek menggunakan purposive sampling. Subjek dalam penelitian ini ada 3 mahasiswa. Teknik analisis data yang digunakan dalam penelitian ini adalah trianggulasi metode yaitu metode tes dan wawancara. Analisis data yang dilakukan menggunakan metode perbandingan tetap mencakup: reduksi data, kategorisasi data, sintesisasi, diakhiri dengan hipotesis kerja. Hasil dari penelitian ini adalah Learning Obstacle mahasiswa dengan kemampuan awal tinggi dan sedang pada fungsi pembangkit terletak pada kesalahan konsep dan operasi; Learning Obstacle mahasiswa dengan kemampuan awal rendah pada fungsi pembangkit terletak pada kesalahan operasi; kesalahan prinsip, kesalahan konsep.
\end{abstract}

Kata kunci : learning obstacle, fungsi pembangkit, kemampuan awal

\begin{abstract}
The purpose of this research is to find out the learning obstacles of students who will be described based on various types of errors in solving problems of generating functions in terms of initial abilities. This type of research is descriptive with a qualitative approach, by taking the subject using purposive sampling. The subjects in this study were 3 students. The data analysis technique used in this study was the triangulation method, namely the test and interview methods. Data analysis performed using the fixed comparison method includes: data reduction, data categorization, synthesis, ending with a working hypothesis. The results of this study are the Learning Obstacle of students with high and medium initial ability in generating functions located in concept and operation errors; Learning Obstacle students with low initial ability in the generator function lie in operating errors; principle error, concept error.
\end{abstract}

Keywords: learning obstacle, generator function, initial ability

\section{PENDAHULUAN}

Fungsi pembangkit merupakan salah satu materi pada matakuliah matematika diskrit. Fungsi pembangkit dikembangkan untuk menangani batasanbatasan khusus dalam pemilihan dan permasalahan menyusun objek dengan pengulangan. Fungsi pembangkit sangat 
berguna pada kehidupan sehari-hari dan berguna pada soal-soal olimpiade. Fungsi pembangkit juga menuntut mahasiswa untuk berpikir kritis dan kreatif. Untuk itu sangatlah penting mempelajari sangat penting.

Namun setelah dilakukan observasi ditemukan bahwa banyak mahasiswa yang memperoleh nilai masih direntang cukup, kurang baik, dan sangat kurang baik. Hal ini memberikan indikasi bahwa mahasiswa masih banyak melakukan kesalahan dalam menyelesaikan soal fungsi pembangkit. Untuk itu perlu dikaji tentang kesalahan-kesalahan yang dilakukan mahasiswa dalam menyelesaikan soal pada fungsi pembangkit. Dengan mengetahui kesalahan - kesalahan yang dilakukan oleh mahasiswa diharapkan dapat memberikan dasar atau acuan dalam melakukan perbaikan.

Kesalahan mahasiswa dalam menyelesaikan soal menjadi learning obstacle (hambatan belajar) mahasiswa. Hambatan belajar dalah suatu hal yang menghalangi tercapainya tujuan yang ingin dicapai dalam belajar. G. Brousseau (1997) menyatakan ada tiga faktor penyebab munculnya hambatan belajar (learning obstacle), yaitu hambatan ontogeny (kesiapan mental belajar), hambatan didaktis (akibat pengajaran atau bahan ajar) dan hambatan epistimologis (pengetahuan siswa yang memiliki konteks aplikasi terbatas). Hambatan epistimologi dekat kaitannya dengan hambatan kognitif. Sedangkan hambatan kognitif terjadi ketika mengalami kesulitan dalam proses belajar. Proses belajar berkaitan erat dengan pengajar, pelajar, dan sistem pengetahuan.

Kesalahan dalam menjawab soal berbeda - beda sesuai dengan tingkat kemampuannya masing-masing. Jenis kesalahan tersebut dapat dilihat dari objek kajiannya. Sukirman (2001:14) mengidentifikasi bahwa kesalahan yang banyak diperbuat oleh pelajar adalah aspek penguasaan bahan pelajaran yaitu (a) kesalahan konsep merupakan kesalahan dalam memahami istilah simbol dan simbol matematika, pemilihan satuan; (b) kesalahan prinsip didefinisikan jika salah dalam menetapkan serta menentukan rumus, menetapkan apa yang diketahui, serta salah dalam menghubungkan konsep yang berkaitan; (c) kesalahan operasi yaitu pelajar dikatakan salah operasi apabila salah dalam penggunaan operasi hitung.

Ada banyak faktor yang bisa mempengaruhi mahasiswa dalam mempelajari materi fungsi pembangkit baik dari dalam diri mahasiswa itu sendiri maupun dari luar diri mahasiswa. Salah 
satu faktor dari dalam diri mahasiswa yaitu kemampuan awal yang dimiliki oleh mahasiswa. Dalam belajar materi fungsi pembangkit akan melatih mahasiswa terampil dalam berpikir. Karena itu pembelajarannya harus dirancang sedemikian rupa sehingga mampu merangsang berpikir dan mendorong mahasiswa menggunakan pikirannya secara sadar untuk menyelesaikan masalah fungsi pembangkit, sehingga dalam merancang pembelajaran perlu memperhatikan kemampuan awal mahasiswa.

$$
\text { Suparman, Atwi }
$$
menyata-kan bahwa kemampuan awal adalah pengetahuan dan keterampilan yang telah dimiliki seseorang sebelum dimulai pembelajaran. Hasil penelitian Nurmitasari (2016) menunjukan bahwa terdapat perbedaan rerata prestasi belajar pada masing-masing kemampuan awal siswa. Hal ini memberikan arti bahwa kemampuan awal memiliki peran penting dalam menentukan keberhasilan mahasiswa. Untuk itu dengan memperhatikan kemampuan awal untuk menganalisis kesalahan mahasiswa dalam menyelesaikan soal fungsi pembangkit akan memberikan pengetahuan dan menjadi bahan pertimbangan dalam melakukan perbaikan pada proses pembelajaran. Kemampuan awal mahasiswa akan diklasifikasikan memjadi tiga tingkatan yaitu kemampuan awal tinggi, sedang, dan rendah.

Berdasarkan uraian tersebut, maka peneliti ingin melakukan penelitian yang bertujuan untuk mengetahui learning obstacles mahasiswa yang akan dideskripsikan berdasarkan berbagai jenis kesalahan dalam menyelesaikan soal fungsi pembangkit ditinjau dari kemampuan awal.

\section{METODE PENELITIAN}

Jenis penelitian ini adalah deskriptif dengan pendekatan kualitatif. Melalui pendekatan kualitatif ini, semua fakta baik lisan atau tulisan dari sumber data yang telah diamati dan dokumen yang terkait lainnya, dideskripsikan apa adanya. Peneliti akan merencanakan, merancang, melaksanakan, mengumpulkan, menganilisis data, meyimpulkan, dan membuat laporan penelitian (Moleong, 2009 : 168).

Subjek dalam penelitian ini adalah 9 orang mahasiswa semester VI program studi pendidikan matematika STKIP MPL yang sesuai dengan kategori kemampuan awal. Pengambilan sampel dilakukan dengan purposive sampling. Instrumen utama dalam penelitian ini adalah peneliti sendiri. Sedangkan instrumen bantunya adalah soal tes 
identifikasi learning obstacle, pedoman wawancara dan Digital Voice Recorder untuk merekam.

Prosedur pengumpulan data dimulai dari metode dokumentasi untuk mendapatkan nilai mahasiswa guna mengkategorikan kemampuan awal yang dimiliki mahasiswa, kemudian dianalisis diperoleh mahasiswa dengan kategori dari masing-masing karakteristik, diperoleh subjek penelitian. Setelah itu subjek diberi soal tes identifikasi learning obstacle, selanjutnya peneliti menganalisis hasil pekerjaan mahasiswa. Kemudian peneliti mempelajari lebih mendalam hasil pekerjaan dan melakukan wawancara kepada subjek penelitian. Langkah berikutnya yakni menganalisis data menggunakan triangulasi metode. Trianggulasi metode adalah membandingkan dua buah metode yang berbeda untuk menjamin keakuratan data.

Analisis data yang dilakukan menggunakan metode perbandingan tetap karena dalam analisis data, secara tetap membandingkan satu datum dengan datum yang lainnya, kemudian secara tetap membandingkan kategori dengan kategori lainnya (Moleong, 2009 : 288). Secara umum proses analisis data tersebut mencakup: reduksi data, kategorisasi data, sintesisasi, diakhiri dengan hipotesis kerja. Reduksi data bertujuan untuk mempermudah pemahaman terhadap data yang telah terkumpul dari hasil catatan lapangan dengan cara mengidentifikasikan bagian terkecil yang ditemukan dalam data yang memiliki makna jika dikaitkan dengan fokus dan masalah penelitian. Kategorisasi adalah upaya memilahmilah setiap satuan ke dalam bagianbagian yang memiliki kesamaan. Mensintesiskan berarti mencari kaitan antara satu kategori dengan kategori lainnya. Menyusun hipotesis kerja, hal ini dilakukan dengan merumuskan suatu pernyataan yang proporsional. Hipotesis kerja ini sudah merupakan teori substantif yaitu teori yang berasal dan masih terkait dengan data. Hipotesis kerja tersebut terkait dan sekaligus menjawab pertanyaan penelitian.

\section{HASIL PENELITIAN DAN PEMBAHASAN}

Berdasarkan hasil tes identifikasi learning obstacle pada fungsi pembangkit dan wawancara yang telah dilakukan peneliti kepada subjek penelitian diperoleh data sebagai berikut:

a. Subjek dengan kemampuan awal rendah

Dari hasil tes identifikasi learning obstacle dan wawancara diperoleh data sebagai berikut: (1) subjek menunjukan kesalahan penulisan deret pada formula fungsi pembangkit ekponensial (deret 
yang dikerjakan subjek berhingga, hal ini tidak sesuai dengan apa yang ditanyakan) serta tidak dapat meng- hitung (salah dalam menghitung perkalian) dan tidak dapat mendistri- busikan perkalian terhadap penjumlahan; (2) subjek tidak bisa memahami syarat yang diberikan pada soal untuk membentuk deret tailor fungsi pembangkit biasa; (3) subjek tidak dapat menghitung operasi perpangkatan.

b. Subjek dengan kemampuan awal sedang

Dari hasil tes identifikasi learning obstacle dan wawancara diperoleh data sebagai berikut: (1) subjek menunjukan tidak terdapat banyak kesalahan, subjek tidak menyelesaikan pekerjaaannya karena sudah tidak bisa melanjutkan kelangkah berikutnya karena belum ada contohnya; (2) subjek juga salah dalam penggunaan simbol; (3) subjek tidak dapat menyelesaikan soal dikarenakan tidak bisa mengoperasikan langkah selanjutnya.

c. Subjek dengan kemampuan awal tinggi

Dari hasil tes identifikasi learning obstacle dan wawancara diperoleh data sebagai berikut: (1) subjek menunjukan tidak terdapat banyak kesalahan, akan tetapi belum dapat selesai menjawab apa yang ditanyakan; (2) subjek salah dalam menggunaan simbol; (3) subjek tidak dapat menyelesaikan soal dikarenakan tidak bisa mengoperasikan langkah selanjutnya.

Subjek dengan kemampuan awal rendah kesalahan yang ditemukan yaitu salah dalam menggunakan rumus yang ekuivalen, kesalahan dalam menentukan yang diketahui, salah dalam menentukan rumus yang digunakan, dan tidak dapat menghubungkan konsep yang saling berkaitan. Kesalahan-kesalahan tersebut termasuk kedalam kesalahan prinsip. Kemudian ditemukan kesalahan dalam mengoperasikan bilangan yang merupakan kesalahan operasi. Selanjutnya kesalahan tidak memahami definisi fungsi pembangkit yang merupakan kesalahan konsep. Kesalahan konsep merupakan kesalahan dalam memahami istilah simbol dan simbol matematika, pemilihan satuan. Contohnya: (1) Salah dalam memahami pengertian serta definisi dari variabel, koefisien, konstanta, suku-suku sejenis dan koefisien dari variabel; (2) Salah dalam memahami istilah matematika yang digunakan; (3) Tidak memahami istilah matematika; (4) Salah dalam memahami simbol. Learning obstacle yang ditunjukan oleh mahasiswa kemampuan awal rendah adalah kesalahan konsep, prinsip,dan operasi. 
Untuk subjek kemampuan awal sedang ditemukan kesalahan bahwa tidak dapat melanjutkan kelangkah berikutnya, termasuk kedalam kesalahan operasi. Kemudian kesalahan yang dilakukan subjek dengan kemampuan awal sedang yaitu salah dalam memahami simbol yang merupakan kesalahan konsep. Learning obstacle yang ditunjukan oleh mahasiswa kemampuan sedang rendah adalah kesalahan konsep, dan operasi.

Untuk subjek dengan kemampuan awal tinggi ditemukan kesalahan yaitu tidak dapat melanjutkan kelangkah berikutnya, termasuk kedalam kesalahan operasi. Kemudian kesalahan yang dilakukan subjek dengan kemampuan awal tinggi yaitu salah dalam memahami simbol yang merupakan kesalahan konsep. Learning obstacle yang ditunjukan oleh mahasiswa kemampuan awal tinggi adalah kesalahan konsep, dan operasi.

Hasil penelitian ini menunjukkan bahwa kemampuan awal mahasiswa mempengaruhi banyaknya kesalahan yang dilakukan mahasiswa dalam menyelesaikan fungsi pembangkit. Kemampuan awal adalah kemampuan prasyarat yang dimiliki mahasiswa sebelum mempelajari materi. Adapun salah satu prasyarat materi fungsi pembangkit adalah kombinatorial. Terdapat temuan dalam penelitian Robia
Astuti (2017) yang menunjukan bahwa terdapat kesalahan dalam melakukan perhitungan dan prosedur, serta kesalahan dalam mengaplikasi konsep atau algoritma pemecahan masalah. Jadi kemungkinan untuk memperbaiki kesalahan-kesalahan yang dilakukan mahasiswa pada materi fungsi pembangkit yakni temukan dulu kesalahan pada materi prasyaratnya kemudian diperbaiki.

\section{SIMPULAN}

Berdasarkan analisis data dan pembahasan yang telah dijelaskan pada bab IV maka diperoleh simpulan bahwa:

a. Learning Obstacle mahasiswa dengan kemampuan awal rendah pada fungsi pembangkit terletak pada kesalahan konsep, kesalahan operasi dan kesalahan prinsip. Kesalahan konsep terletak pada ketidakmampuannya dalam memahi definisi fungsi pembangkit. Kesalahan prinsip terletak pada salah dalam menggunakan rumus yang ekuivalen, kesalahan dalam menentukan yang diketahui, salah dalam menentukan rumus yang digunakan, dan tidak dapat menghubungkan konsep yang saling berkaitan. Kesalahan operasi terletak 
pada kesalahan dalam mengoperasikan bilangan.

b. Learning Obstacle mahasiswa dengan kemampuan awal sedang pada fungsi pembangkit terletak pada kesalahan konsep dan kesalahan operasi. Kesalahan konsep terletak pada kesalahan penggunaan simbol. Kesalahan operasi terletak pada ketidakmampuannya melanjukan operasi berikutnya sehingga soal tidak diselesaikan dengan sempurna.

c. Learning Obstacle mahasiswa dengan kemampuan awal tinggi pada fungsi pembangkit terletak pada kesalahan konsep dan kesalahan operasi. Kesalahan konsep terletak pada kesalahan penggunaan simbol. Kesalahan operasi terletak pada ketidakmampuannya melanjukan operasi berikutnya sehingga soal tidak diselesaikan dengan sempurna.

\section{DAFTAR PUSTAKA}

G. Brousseau. 1997. Theory of Didactical in Mathematic. Drodrecht : Kluwer Academic Pulisher

Moleong, L. J. (2009). Metodologi Penelitian Kualitatif: Edisi Revisi. Bandung: PT Remaja Rosdakarya.

Nurmitasari. 2016. Pembelajaran Team Assisted Individualization pada Lingkaran ditinjau dari Jenis Kelamin dan Kemampuan Awal. Jurnal Eksponen STKIP
Muhammadiyah Kotabumi. Vol. 6.No. 3 .
Robia Astuti. 2017. Analisis Learning Obstacle Mahasiswa Dalam Mempelajari Materi Kombina- torial. Jurnal e-dumath STKIP Muhammadiyah Pringsewu Lampung. Vol. 3. No.1

Sukirman. 2001. Evaluasi Pembelajaran. Yogyakarta : Multi Pressindo.

Suparman, Atwi. 2001. Desain Intraksional. Jakarta : Depdikbud 